\title{
POLICY ANALYSIS OF OCCUPATIONAL HEALTH IMPLEMENTATION AT R. SYAMSUDIN, SH. HOSPITAL, SUKABUMI, WEST JAVA
}

\author{
Ni Putu Juwanita Dewi¹, Puput Oktamianti², Nitasari3 \\ 1)Master Program in Public Health, Faculty of Public Health, Universitas Indonesia \\ ${ }^{2}$ Health Policy Administration, Faculty of Public Health, Universitas Indonesia \\ 3)R. Syamsudin, SH Hospital, Sukabumi, Indonesia
}

\begin{abstract}
Background: The Occupational Health and Safety Act aims to ensure healthy and safe working conditions of workers. Although some organizations have worked hard to safeguard their employees' health and protect them from work-related hazards, their programmes have not been guided by any specific policy or workplace health promotion framework. The purpose of this study was to use the theoretical framework of Van Meter and Van Horn including policy standards and objectives, resources, implementing agency characteristics, communication between organizations, implementing dispositions and support of socio-economic and political environments as a framework to examine policy analysis of occupational health implementation at R. Syamsudin, SH. hospital, Sukabumi, West Java.

Subjects and Method: This was a qualitative study conducted at R. Syamsudin, SH. hospital in Sukabumi, West Java. A sample of 17 health workers was selected for this study. The dependent variable was the implementation of occupational health. The independent variables were policy standards and objectives, resources, implementing agency characteristics, communication between organizations, implementing dispositions and support of socio-economic and political environments. The data were collected by depth-interview, observation and document review.

Results: The implementation of occupational health policy in R. Syamsudin, SH hospital was found not optimally implemented.

Conclusion: The implementation of occupational health policy in RSUD R. Syamsudin, SH. Sukabumi city is not optimally implemented. Theoretical framework of Van Meter and Van Horn can be used to analysis the implementation of occupational health.
\end{abstract}

Keywords: occupational health, policy implementation, van meter, van horn

\section{Correspondence:}

Ni Putu Juwanita. Master Program in Public Health, Faculty of Public Health, Universitas Indonesia. Email: happynitadewi@gmail.com. Mobile Phone: 0817438713.

\section{BACKGROUND}

Healthy is a fundamental right for humans and it is universal. United Nations Declaration on Human Rights (1948) stated that everyone has human rights to work, free to choose a job, get fair employment conditions, and make a prosperous life. Meanwhile, in the United Nations Interna-
}

tional Covenant on Economic Affairs, Social and Cultural Rights was restated on the importance of having safe and healthy working conditions as fundamental human rights. In addition to the Declaration of Alma Ata (1978), the Work Health Assembly (WHA) stated that giving high priority to employee health in its work 
program.

Attention to employee work health is still rarely to become a top priority by some businessmen or business owners. This can be seen from the lack of awareness to conduct health promotion activities and preventive efforts, one of which is the low of health check as a preventive measure of non-communicable diseases (PTM) in both developed and developing countries. According to a study conducted in Germany in 2010, it was found that the profile of patients undergoing health checks was $28.9 \%$. Patients routinely engaged in physical activity, were accustomed to consuming vegetables and fruit and were not smoking (Hoebel et al., 2014). In Malaysia, male participants who took health examinations aged 20-69 years amounting to $41.9 \%$ (Teo \& White, 2017). While in Indonesia the study using employee health checks is still not much done.

One of the programs in Indonesia is the Healthy Living Community Movement a.k.a GERMAS which is the focus of activities in 2017. The instructions of GERMAS are to make regular physical activities, improve the implementation of early detection of diseases, check routine health in all government and private institutions.

A healthy living and health service as a part of GERMAS applies to the Regional General Hospitals. The director of hospital management carrying out health checks for employees in order to do early detect diseases for employees in the hospital where the workplace is susceptible to disease, exposed to the risk of non-communicable diseases, and involves various multi-professions in working environment in the hospital. Suprihanto stated that work productivity is the ability of economic resources to produce something or interpreted as a comparison between input and output (Anwar, 2014). Employee health factors greatly affect the level of productivity associated with optimal work results. In order for employees to perform their functions optimally, they must be supported by excellent health conditions through health checks.

Health Regulation Number 66 of 2016 concerning the Safety and Health of Hospital Work ( $\mathrm{K}_{3} \mathrm{RS}$ ), states that occupational health services carried out by $\mathrm{K}_{3} \mathrm{RS}$ are carried out comprehensively through activeties that are promotive, preventive, curative, and rehabilitative. R. Syamsudin, SH Hospital in Sukabumi West Java is a type B Educational Regional General Hospital and as a regional referral hospital for the area ofJampang Kulon, the port of Queen and surrounding areas. In 2011, the hospital has improved the quality of implementation of integrated management system services for quality, safety, and occupational safety. Using reference to ISO 9001: 2008 by obtaining a Quality System Certificate Regulation 288-07/131), OHSAS 18001: 2007 with certificates of Occupational Health and Safety (K3) System Certificate Reg. 06-11/06, and ISO 14001: 2004 with Environmental Management System Certificate Regulation 05-11/05.

R. Syamsudin, SH Hospital has carried out the 2012 version of the Accreditation of Hospitals accredited by Hospital Accreditation Committee 
(KARS) and received the plenary pass predicate in 2016, besides being named Green Global Hospital which emphasizes the aspect of no harm that aims to ensure safety and the health of patients, hospital staff and the community around the hospital. This is a challenge because the hospital with 1621 employees from various professions must pay attention to the occupational health aspects of the employees.

R. Syamsudin, SH. Hospital follows up with the Minister of Health Regulation Number 66 of 2016 concerning Occupational Safety and Health by issuing Director Decree Number 88 of 2017 concerning Guidelines for Occupational Health Services, the Director's Decree one of which stipulates employee health promotion activities consisting of fitness exercises and regular recitation for employees, preventive activities which include types of health checks for employees consisting of health checks before work, periodic health checks, special health checks, and post-employment health checks on workers who will retire. Curative activities include services for occupational health clinics for hospital employees, as well as rehabilitative activities for employees in the form of a return to work program for employees after experiencing severe illness or injury.

Based on occupational health activities for employees that have been carried out in R. Syamsudin, SH Hospital, found that employees who participated in promotive activities were still minimal, around 40-50 people in one promotive activity, employees who had periodic health checks only $7.2 \%$, and examination results show that employees have PTM risks. The curative efforts have not been optimal even though there are already occupational health clinics for employees. The rehabilitative efforts have been carried out in R. Syamsudin, SH Hospital.

Based on the data related to the occupational health policy in $\mathrm{R}$. Syamsudin, SH Hospital, it is known that the policy was only implemented in 2017 in the form of an early detection of the risk of disease for 133 employees, a periodic health check of 40 employees, and hepatitis B immunization for 100 employees. The regulation of the Minister of Health Number 66 in 2016 of R. Syamsudin, SH Hospital has not been well implemented.

Van Meter Theory Van Horn in Winarno (2007) described that policy implementation is an abstraction basically intentionally carried out to achieve implementation performance. According to this theoretical model, implementation is influenced by six variables: basic measures and policy objectives, policy sources, characteristics of implementing agents, communication between organizations, dispositions or inclinations of executors and social, economic, and political environment. The policy implementation theory (Edward III, 1980) in Winarno (2007) described that policy implementation is a crucial process involving four variables in implementation, namely communication, resources, disposition or attitude, and bureaucratic structure. Van Meter and Van Horn (1975) in Ayuningtyas (2018) argued that policy 
implementation is an action taken by individuals or government and private groups to achieve the goals set in policy decisions.

The model introduced by Donald Van Meter and Carl Van Horn (1975). This model assumes that policy implementation runs linearly from public policy, implementers and public policy performance. According to this model, there are six variables included as variables that influence public policy, namely policy standards and objectives, resources, characteristics of implementing agencies, dispositions or attitudes of executors, communication between related organizations and implementation activities, as well as social, economic and politics (Nugroho, 2017).

There are several variables that influence a policy including the variable characteristics of implementing agencies as stated by Van Meter and Van Horn in Agustinus (2006) so this discussion cannot be separated from the bureaucratic structure. The bureaucratic structure is defined as the characteristics, norms and patterns of repetitive relationships in bodies that have a potential or real relationship to what they have in order to carry out the policy. Incentives are seen as a form of resource optimization to get maximum support from implementers. Providing positive incentives (in the form of fulfilling personal interests) and imposing sanctions that are considered to be able to improve and generate positive executive support (Yalia, 2014). Incentives are seen as an attractive and important package in maintaining and motivating workers. (Henderson, 2008).
The theoretical framework used in this study is the theory of policy implementation by Van Meter Van Horn. This theory states that there are six variables as determinants of the success of a policy, namely policy standards and objectives, resources, characteristics of the implementing agency, disposition or tendency of the implementers, communication between related organizations and implementation activities as well as social, economic and political environment.

\section{SUBJECTS AND METHOD \\ 1. Study Design \\ This was a qualitative study with Ra- pid Assessment Procedures (RAP) ap- proach. This study was carried out in R. Syamsudin, SH Hospital in Suka- bumi, West Java from March to May 2018.}

\section{Study Informants}

Total 17 informants was selected for this study, consisting of one key informant who came from the Directorate of Occupational Health and Sport at the Ministry of Health, in addition 2 people came from the Sukabumi City Health Office, 14 people from RSUD R. Syamsudin, SH. Sukabumi City.

\section{Data Analysis}

The data were obtained using indepth interviews, observation, and documentation. The technique of analyzing data is data collection, presentation, reduction, collection, and conclusion.

$\frac{\text { RESULTS }}{\text { 1. Hospital Employees Status }}$
The employees status of R. Syam-
sudin, SH Hospital included Civil Ser-


vants (PNS), Contracted Employee (TKK) and Officers of Daily Paid Workers (PHL). The descripttion of $\mathrm{R}$.
Syamsudin, SH Hospital employees for the past three years were describeed in table 1 and 2.

Table 1. Hospital Employees Status

\begin{tabular}{ccccc}
\hline Year & \multicolumn{3}{c}{ Employee Status } & Total \\
\cline { 2 - 4 } & $\begin{array}{c}\text { Civil } \\
\text { Servant }\end{array}$ & $\begin{array}{c}\text { Contracted } \\
\text { Employee }\end{array}$ & $\begin{array}{c}\text { Officers of } \\
\text { Daily Paid } \\
\text { Workers }\end{array}$ & \\
\hline 2016 & 681 & 786 & 22 & 1489 \\
2017 & 659 & 931 & 36 & 1626 \\
2018 & 641 & 949 & 30 & 1621 \\
\hline & & & \multicolumn{2}{c}{ Source: HRD department }
\end{tabular}

Table 2. Hospital Employees Competence

\begin{tabular}{lc}
\hline \multicolumn{1}{c}{ Employee } & Total \\
\hline Medical Staff & 85 \\
Nursing Staff & 776 \\
Non Nursing Health Supporting Staff & 168 \\
Administration Staff & 592 \\
Total & $\mathbf{1 6 2 1}$ \\
& Source HRD department
\end{tabular}

A total of employees who had sick for 6 days or more in 2017 were 131 (8\%) out of 1,626 employees. A total of 42 employees (32\%) had infectious and parasitic disease, 24 employees had problem due to pregnancy, childbirth and postpartum (18\%), 17 employees (13\%) had digestive system, 11 employees (8\%) had circulatory system diseases, vertigo, diseases of the musculoskeletal system, 6 employees (5\%) had nervous system problem, 4 employees (3\%) had respiratory system and neoplasm problem, and 2 employees (2\%) had diabetes.

The number of employees who were sick for less than 6 days in 2017 were 567 employees (34\%) out of 1,626 employees. A total of $191 \mathrm{emp}-$ loyees (34\%) had infectious and parasitic diseases, 147 employees (26\%) had respiratory system disease, 85 employees (15\%) had digestive system problem, 48 employees (8\%) had problem due to pregnancy, childbirth and postpartum period, 23 employees (4\%) had circulatory system diseases and vertigo, 18 employees (3\%) had injury, 12 employees (2\%) had eye disease and adnexa, 11 employees (2\%) had genitourinary system, and 10 employees (2\%) had musculoskeletal system disease and connective tissue.

The number of employees who had experienced pain for 6 days or more were 13 employees (23\%) from the pharmacy installation area, 7 employees (12\%) from the outpatient installation, 6 employees (10\%) from the medical record area, the park and building area, and the registration area of the emergency room, 6 employees (10\%) from the Surgical Family Room, 4 employees (7\%) from the Central Surgical Installation area and the obstetric room, and 3 employee (5\%) from the emergency room area 
and the surgical family room.

\section{Van Horn theory and Van Meter}

a. Socialization of the Work Health Policy

The implementation of employee work health activities at R. Syamsudin, SH Hospital was carried out by means of a special Whatssap Group formed by $\mathrm{K}_{3} \mathrm{RS}$ unit which included the chief nurse of the room, the head of the unit, and the installation in the hospital so that the information provided by the $\mathrm{K}_{3} \mathrm{RS}$ unit would be disseminated to the employees below.

\section{b. Health Promotion Efforts}

The efforts of promotive activities that had been held in R. Syamsudin, SH Hospital were fitness exercises and regular recitation for employees. The promotive activities in R. Syamsudin, SH Hospital was not optimal because the number of employees participating in the activity was still minimal because the implementation schedule collides with working hours, while there was no list of attendees found for those who participate in the activity. It was found that the additional nutrition feeding program for employees who did the night service was not carried out in R. Syamsudin, SH Hospital and the hospital management agreed to replace the program with a policy of giving side dishes (ULP) for employees every month.

\section{c. Activity Efforts are Preventive}

The preventive activities that had been carried out were FR-PTM early detection as many as 133 employees, periodic health checks for as many as 40 employees with criteria for work- ing in risk areas and aged 40 years and over and giving diphtheria and hepatitis immunization had been carried out in stages but not all employees had received the immunization. Pre-employment health checks had been carried out. Special and postemployment health checks, medical surveillance, and work environment surveillance had not been carried out.

\section{d. Curative Activities}

The curative activities carried out were the existence of an occupational health clinic for employees based on the Director's Decree Number 60 of 2017 concerning Occupational Health Clinics in R. Syamsudin, SH Hospital. Most of the employees and structural officials of the hospital did not know the existence of the occupational health clinic

\section{e. Efforts to be Rehabilitative Activi- ties}

The rehabilitative activities for employee health that had been carried out were the program to return to work after the employee experienced severe illness. There were 3 employees who have undergone this program.

\section{f. Recording and Reporting of Occupational Health Activities}

Reports on employee work health activities made by the $\mathrm{K}_{3} \mathrm{RS}$ unit are submitted to the Director and the report would be re-positioned to the $\mathrm{K}_{3} \mathrm{RS}$ Unit and used as an archive by the $\mathrm{K}_{3} \mathrm{RS}$ Unit, but the recording and reporting had not been carried out periodically by the $\mathrm{K}_{3} \mathrm{RS}$ Unit while for reporting the occupational health activities of employees in the hospital, 
it has not been reported by R. Syamsudin, SH Hospital Sukabumi City to Sukabumi City Health Office.

\section{g. Monitoring and Evaluation of Oc- cupational Health Activities}

Monitoring and evaluation of employyee occupational health activeties was carried out by direct observation by the $\mathrm{K}_{3} \mathrm{RS}$ Unit but had not been carried out periodically and there is no document for monitoring employee work health evaluation and minutes of monitoring and evaluation meetings at R. Syamsudin, SH Hospital Sukabumi City.

h. Standards and Objectives

The implementation of employee work health programs or activities that are promotive, preventive, curative and rehabilitative in an optimal manner in order to realize occupational health for employees in the R. Syamsudin, SH Hospital Sukabumi City and followed up in Director Decree Number 88 of 2017 concerning Guidelines for Health Services in R. Syamsudin, SH Hospital Sukabumi City. Realization of the standards that have been determined in accordance with the Regulation of the Minister of Health No. 66 of 2016 has not been fully realized in R. Syamsudin, SH Hospital Sukabumi City.

\section{i. Resources}

The resources in this study cover budgetary resources that are still being budgeted for employee occupational health activities and in 2018 budgeted for preventive activeties and purchase of tools for occupational health programs totaling Rp 232,817,000, while the facilities in RSUD R. Syamsudin still need purchases for the tools of occupational health programs for employees, and there is no special incentive for policy implementers who have carried out occupational health at the R. Syamsudin, SH Hospital Sukabumi City.

j. Characteristics of the implementing agency

The characteristics of the implementing agency in this study cover how human resources are still limited in quality because they do not have much knowledge and special experience in the $\mathrm{K}_{3} \mathrm{RS}$ field and the number of employees consists of 4 people who make it vulnerable to the accumulation of $\mathrm{K}_{3} \mathrm{RS}$ jobs, bureaucratic fragmentation is quite high because $\mathrm{K}_{3} \mathrm{RS}$ units involve other units or parts such as staffing, service, support, pharmaceutical installations, hospital infrastructure facilities, general departments, finance departments to carry out occupational health activities, while inter-organizational relations are carried out with the City Health Office as coaches of employee occupational health activities in hospitals and BPJS Health and BPJS Employment has a role as a supporter in the implementtation of the work health policy of employees in $\mathrm{R}$. Syamsudin, SH Hospital Sukabumi City.

\section{k. Communication}

Communication between organizations in this study includes clarity from policy makers to implementing policies and between organizations in organizing work health policies of employ- 
yees in hospitals, implementing policies to communicate with official letters between organizations, communication media such as telephone and whatsaap. In terms of consistency of policy implementers in R. Syamsudin, SH Hospital applied Permenkes No. 66 of 2016 as a reference for the implementation of occupational health at the hospital employees, there is no mechanism or procedure or SOP related to occupational health for employyees in R. Syamsudin, SH Hospital

\section{l. Disposition}

Disposition in this study covers the response of policy implementers who accept employee health policies because they are included in the hospital version of the accreditation assessment element, while for their understanding of the occupational health policy, the majority knows only in an outline and the intensity of implementing periodic policies at certain times. Socio-economic politicalenvironment. The socio-economic political environment in this study encompasses external support from the social environment that is sufficient to support the successful implementtation of occupational health policies for employees in hospitals, namely the support of hospital employees who support employee occupational health activeties, not yet seen support from the economic and political environment conducted by local governments or local government figures such as mayors and deputy mayors in the form of budget assistance for the implementation of occupational health activities for hospital employyees.

The implementation of employee work health policies (table 3) as well as variables consisting of policy standards and objectives, resources, organizational body characteristics, disposition, communication between organizations and the socio-economic political environment found in this study scoring to assess whether R. Syamsudin, SH Hospital Sukabumi City has implemented an employee health policy optimally or not optimally. Indicators of Implementation of Employee Work Health Policy are described in Table 3.

\section{Table 3. Result of Implementation}

\begin{tabular}{lccc}
\hline \multicolumn{1}{c}{ Indicator } & $\begin{array}{c}\text { Not Running } \\
\text { Yet }\end{array}$ & $\begin{array}{c}\text { Run } \\
\text { Optimally }\end{array}$ & $\begin{array}{c}\text { Already running } \\
\text { but not optimal yet }\end{array}$ \\
\hline Promotive activities & & $\sqrt{ }$ \\
Preventive activities & & $\sqrt{ }$ \\
Curative activities & & $\sqrt{ }$ \\
Rehabilitation activities & & $\sqrt{ }$ \\
Socialization activities & & $\sqrt{ }$ \\
Recording and reporting & & \\
activities & $\sqrt{ }$ & \\
Monitoring and & & $\sqrt{ }$ \\
evaluation activities & & \\
Policy standard and & & \\
objectives & & \\
Budget & & & \\
\hline
\end{tabular}




\begin{tabular}{lcc}
\hline Facility & $\sqrt{ }$ & $\sqrt{ }$ \\
$\begin{array}{l}\text { Incentive } \\
\text { Resources }\end{array}$ & $\sqrt{ }$ & $\sqrt{ }$ \\
$\begin{array}{l}\text { SOP } \\
\text { Bureaucratic Fragmen- } \\
\text { tation }\end{array}$ & $\sqrt{ }$ & \\
$\begin{array}{l}\text { Relationship between } \\
\text { organization }\end{array}$ & & $\sqrt{ }$ \\
$\begin{array}{l}\text { Communication } \\
\text { Transition } \\
\text { Clarity }\end{array}$ & & \\
$\begin{array}{l}\text { Consistency } \\
\text { Political, Social Economic }\end{array}$ & & $\sqrt{ }$ \\
$\begin{array}{l}\text { Environment } \\
\text { Disposition }\end{array}$ & $\sqrt{ }$ \\
Total & & $\sqrt{ }$ \\
\hline
\end{tabular}

Based on the Table 3, it can be seen that out of 20 indicators of the implementation of employee work health policies, 16 of them were implemented but not optimal in order to support the implementation of the work health policies of hospital employees. There are 3 indicators that are completely absent are incentives for employees, SOPs for employee health policies and monitoring and evaluation of occupational health activities for employees in hospitals.

\section{DISCUSSION}

The implementation of the employee work health policy is not optimal because it is influenced by the disposition or tendency of the implementing attitude that is still weak, this can be seen from the attitude of the implementer who accepts the policy because it tends to fulfill hospital accreditation and understanding of the implementers who know the occupational health policy is not comprehensive and complete the intensity of implementing attitudes that are still rare for employee occupational health activities, so that the standards and objectives of the work health policy of employees have not optimally reached the target targets and their realization has not been optimally implemented in R. Syamsudin, SH Hospital Sukabumi City.

Disposition of the implementers was still weak because based on the characteristics of the implementing agency, the hospital is still not optimal in implementing the employee's occupational health policy, this is evident from the fairly high fragmentation between fields or sections, resulting in unclear authority of the perpetrators who implement employee health policies, as well as sources human resources that have not been optimal in quality and quantity in supporting the implementation of employee work health in the hospital as well as inter-organizational relationships that have not been optimally carried out periodically for the implementation of employee work health policies, it affects the disposition of policy implementers and influences 
the implementation of employee work health in hospitals R. Syamsudin, SH. Sukabumi City.

The implementation of the employee's occupational health policy in R. Syamsudin, SH Hospital and the disposition of the performers who are still not optimal is also influenced by external support, namely from the social, economic and political environment that is not optimal in supporting the work health policy of hospital employees because there is no support related to occupational health employees in the Regional Medium Term Development Plan (RPJMD) and then have not been followed up in the Health Service strategic plan (renstra), thus causing the absence of an optimal work plan and budget for the implementation of employee health policies especially in hospital.

Standards and policies that have not been clearly understood by policy implementers have caused weak implementation attitudes in supporting occupational health policies so that the impact on the implementation of occupational health in $\mathrm{R}$. Syamsudin, SH hospitals have not run optimally.

Communication between organizations is still not optimal in supporting the implementation of employment health policies for employees because there is no standard mechanism/ procedure/ SOP for employee work health activities in the hospital, which causes unclear authority in carrying out the work health of hospital employees. With the Standard Operations Procedures/ SOPs, all mechanisms/ procedures related to occupational health activeties become clearer and more focused while for clarity on occupational health policies only clearly understood by the $\mathrm{K}_{3} \mathrm{RS}$ Unit and hospitals trying to consistently implement Ministry of Health Regulation No. 66 of 2016.

Weak resources, which consist of limited budgets and facilities to support the implementation of health policies for hospital employees, meanwhile there is no incentive given to policy implementers which causes the implementing attitude to be weak in implementing the policy.

Unoptimal resources and communication between organizations that have not been optimally influenced by standards and objectives that have not been clearly defined by policy makers so that the implementation of the work health policy of hospital employees has not been optimally implemented in RSUD $\mathrm{R}$ Syamsudin, SH. Sukabumi City.

\section{REFERENCES}

Agustinus L (2006). Politik dan Kebijakan Publik, $1^{\text {st }}$ ed. Bandung: AIPI.

Anwar, Muhammad (2014). Pengantar Kewirausahaan Teori dan Aplikasi. Jakarta: Penerbit Kencana.

Ayuningtyas D (2015). Kebijakan Kesehatan Prinsip dan Praktik, $3^{\text {rd }}$ ed Jakarta: Penerbit Rajawali Press.

Ayuningtyas D (2018). Analisis Kebijakan Kesehatan Prinsip dan Aplikasi ( $1^{\text {st }}$ edition), Jakarta: Penerbit Rajagrafindo Persada.

Buse K, Mays N, Walt G (2012). Making health policy. Open Univer- 
sity Press. Retrieved from https://books.google.co.id/books/about/Making_Health_Poli cy.html?id=LL1M4lOzXt wC\&redir_esc $=\mathrm{y}$.

Creswell JW (2009). Research design: Qualitative, quantitative, and mixed methods approaches $\left(3^{\text {rd }}\right.$ edition). Thousand Oaks, CA: Sage.

Edward III GC (1980). Implementing Public Policy. Washington: Congressional Quarterly Press.

Hoebel J, Starker A, Jordan S, Richter M, Lampert T (2014). Determinants of health check attendance in adults: findings from the cross-sectional German Health Update (GEDA) study. Retrieved from https://www.ncbi.nlm.nih.gov/pmc/articles/PMC4167266 /pdf/12889_2014_Article_70 31.pdf.

Lyn HN, Jim T. (2008). Incentives for retaining and motivating health workers in Pacific and Asian countries. Human Resources for Health. 6:18. doi: 10.1186/14784491-6-18.

Martha, Kresno (2016). Metodologi Penelitian Kualitatif untuk Bidang Kesehatan. Jakarta: PT Raja Grafindo Persada.

Nugroho, Riant (2017). Public Policy (6 ${ }^{\text {th }}$ Edition). Jakarta: PT Gramedia.

Rusli B (2015). Kebijakan Publik: Membangun Kebijakan Publik yang Resonsif (2 ${ }^{\text {nd }}$ edition). Bandung: CV. Adoya Mitra Sejahtera.

Teo CH, Ng CJ, White A (2017). Factors influencing young men's decision to undergo health screening in Malaysia: a qualitative study. BMJ Open 2017. Retrieved from https://www.ncbi.nlm.nih.gov/pmc/articles/PMC5353258/pdf/bmjopen-2016014364.pdf

Van Meter DS, Van Horn C (1975). The Policy Implementation Process. Sage Publishing Press.

Wahab, Abdul S (2012). Analisis Kebijakan dari Formulasi ke Penyusunan Model-Model Implementasi Kebijakan Publik. Jakarta: Bumi Aksara.

Widodo J (2017). Analisis Kebijakan Publik: Konsep dan Aplikasi Analisis Proses Kebijakan Publik. (S. Wahyudi, Y. Setyorini, \& I. Basuki, Eds.) (10 ${ }^{\text {th }}$ edition). Malang: Media Nusa Creative.

Winarno B (2007). Kebijakan Publik : Teori dan Proses. Jakarta: Penerbit Media Pressindo.

Winarno B (2014). Kebijakan Publik (Teori, Proses dan Studi Kasus). Yogyakarta: Center of Academis Publishing Service (CAPS).

Yalia, Mulyono (2014). Implementasi Kebijakan Pengembangan dan Pemberdayaan Lembaga Sosial Media Tradisional di Jawa Barat 6(1). Bandung: BPPKI. 